\title{
POLICY NETWORKS AND THE DISTINCTION BETWEEN INSIDER AND OUTSIDER GROUPS: THE CASE OF THE COUNTRYSIDE ALLIANCE
}

\author{
DAVID MARSH, DAVID TOKE, CLAES BELFRAGE, DANIELA TEPE AND \\ SEAN McGOUGH
}

\begin{abstract}
Unsurprisingly, a great deal has been written about the role of interest groups in contemporary societies. Here, we focus on two sets of concepts that have had influence in the UK literature: the distinction between 'insider' and 'outsider' groups originally developed by Grant $(1978,2000)$; and the classification of policy networks developed by Marsh and Rhodes (1992; see also Marsh and Smith 2000). We have two aims in this article. First, we use these concepts to consider the role of the Countryside Alliance (CA) in the UK, which, at least in terms of membership numbers and media exposure, is one of the most interesting phenomena on the contemporary interest group scene. Second, we use the case study of the CA to cast light on the utility of these two sets of concepts and consider how they might be integrated. As such, this article is divided into two substantive sections. First, we identify the issues raised in the literature on, first, insider and outsider groups and, then, policy networks. In the second section we examine the role of the CA.
\end{abstract}

\section{CONCEPTUAL DISTINCTIONS}

Any attempt to classify interest groups, or the relations between them and government, is essentially a step towards establishing whether certain types of groups, or groups with particular relations with government, are more influential. In this vein, both Grant's (1978) distinction between insider and outsider groups and Marsh and Rhodes' (1992) distinction between tight policy communities and looser issue networks are clearly linked to an assessment of the influence of such groups. So, to Grant, insider groups are more influential than outsider groups and, to Marsh and Rhodes, interest groups operating within policy communities are more influential than groups operating within issue networks. Interestingly, there has been little attempt to link these two literatures and this is one of the key aims of this article.

\section{Insider, outsider and thresholder groups}

Grant's (1978) typology of interest groups distinguished between insider and outsider groups in terms of the type of contacts they enjoyed with, and the tactics they used in approaching, government. In later work, Grant (1989) developed the distinction, identifying three types of insider groups: high profile insiders, low profile insiders, and prisoner groups; and three types of outsider groups: potential insiders, outsiders by necessity, and ideological outsiders. However, he still strongly defended the basic distinction, arguing (Grant 2000, p. 19) that a limited number of insider groups are members of high status policy committees and are regularly consulted by, and have influence over, government. In Grant's view: 'In the longer run, most groups tend to veer towards an insider strategy because of the potential gains it offers' (Grant 2000, p. 20).

David Marsh is in the Research School of Social Sciences, Australian National University, David Toke is in the Department of Sociology, University of Birmingham, Claes Belfrage is in the School of Humanities, Swansea University, Daniela Tepe is in the School of Social Sciences, Media and Cultural Studies, University of East London and Sean McGough is an independent research consultant. 
To Grant, there is an exchange relationship involved; in return for privileged access, insider groups provide information to government and cooperate in the implementation of policy, thus reducing implementation costs.

To Grant (2000, p. 19), outsider groups, on the other hand, are either unable or unwilling to become: 'enmeshed in a consultative relationship with officials'. In particular, he argues that there will always be 'ideological' outsider groups, committed to campaigning for radical policy change, which cannot be accommodated within existing policy paradigms (2000, p. 19). Nevertheless, the key point for Grant is that the more influential groups don't use outsider tactics and, conversely, that many of those groups who do use these tactics wouldn't do so if they could achieve insider status.

Grant's distinction has since been criticized and developed. For example, May and Nugent (1982) introduced the idea of a 'thresholder' group to help explain the changing interest group behaviour of trade unions, whose contacts with government and the tactics they used fluctuated considerably over time. As such, they argued that many groups are neither insider nor outsider groups; rather, they can be both, although not at the same time. For May and Nugent, their changing status results from changes in the broader political environment and/or the internal organization of the group.

Page (1999) also sees the distinction between insider and outsider groups as problematic, but he suggests that groups can be outsiders on some issues and insiders on others. In addition, he argues, based on a study of the extent to which interest groups self-report consultations with government about forthcoming legislation, that most groups are insider groups, which, of course, supports a pluralist understanding of the distribution of power in the UK.

Maloney et al. (1994, p. 30) are more positive about Grant's distinction, but suggest it needs to be made more sophisticated. As far as insider groups are concerned, they distinguish between 'core', 'specialist' and 'peripheral' groups. However, they emphasize that these differences reflect the status that is accorded to the groups by civil servants, rather than the strategies adopted by the group. As such, they contend that it is crucial to distinguish between 'status' and 'strategy'. Maloney et al. divide outsiders into those who are outsiders by 'ideology or goal' and those who are so 'by choice'. Following May and Nugent, they divide strategies into 'insider', 'outsider' and 'thresholder'.

Binderkrantz (2005) distinguishes between interest groups which pursue 'direct' strategies, approaching politicians or civil servants, and those which follow 'indirect' strategies, using the media or mobilization of supporters. The latter is of particular importance in a period in which groups, like the CA, use the media extensively. However, Binderkrantz's main concern was to examine whether using indirect strategies was a less useful, fallback, position utilized by groups unable to achieve privileged insider status. As such, her aim was to establish whether there was a link between the different strategies pursued and the degree to which the interest groups were 'privileged' or 'non-privileged'.

She used data self-reported by the interest groups and, on that basis, found that there was no clear difference between privileged and non-privileged groups in their use of strategies, suggesting that indirect strategies are not an 'inferior' way of attempting to gain influence. As such, she takes issue with those arguments in the existing literature (see, for example, Maloney et al. 1994, p. 35) which suggest that 'public interest groups or cause groups are (. . .) likely to pursue indirect strategies of influence' (Binderkrantz 2005, p. 698), arguing instead that indirect strategies are used by groups of all sorts to attract members (Binderkrantz 2005, p. 711). 
Overall, both Grant's work and the critiques and extensions of it have suggested that group strategies are more blurred than the original model suggested and, consequently, that the connection between a group's location/strategy and its influence over government is also more complex than Grant initially claimed. More specifically, the literature on insider/outsider groups raises three main questions which we shall address when examining the CA case:

1. Do groups pursue insider and outsider strategies at the same time?

2. Do groups pursue an outsider, or indirect, strategy, particularly using the media, because they have no choice, or do they do it to attract members?

3. Is there a connection between insider status and influence?

\section{Policy networks}

There is a clear link between the literature on insider/outsider groups and that on policy networks, although it is not a link that is acknowledged by Marsh and Rhodes (1992) who do not discuss Grant's distinction. However, in our view, the key value-added of the policy network approach is that it recognizes the fairly obvious point that an individual group's contacts with government are both bi-partite and multi-partite so that there is a network of relationships which are more, or less, formalized and more, or less, tight.

Marsh and Rhodes use policy network as a generic term and suggest that different networks run along a continuum, from policy communities at one end, to issue networks at the other. They characterize policy communities as having the following: (1) a limited number of groups, with others excluded; (2) continuity of membership; (3) frequent high quality interaction between members; (4) broadly shared policy preferences; (5) an acceptance of the legitimacy of outcomes from the network; (6) members who all have resources which they exchange; (7) leaders who can deliver membership support for outcomes; and (8) a broad balance of power between members, so that the result is a positive-sum game. In contrast, issue networks are characterized as having the following: (1) large fluctuating membership; (2) limited interaction; (3) conflicting policy preferences; (4) group leaderships who cannot deliver members; (5) interaction that is often a zero-sum game (Marsh and Rhodes 1992, p. 251). The first point to emphasize here is that there is an obvious overlap between membership of a policy community and insider status and membership of an issue network and outsider status.

In addition, Marsh and Rhodes see British government as characterized by a limited number of tight policy communities which are dominated by three sets of interests: economic/business interest; professional interest; and government. As such, their argument is a direct critique of pluralism; in their critique, the view is that a great deal of power is exercised by members of policy communities.

There has been significant criticism of Marsh and Rhodes' original policy networks approach (see Dowding 1995) and of the related dialectical model of policy networks developed by Marsh and Smith (2000; see Dowding 2001 and, for a response, Marsh and Smith 2001). Here, our focus is on the utility of Marsh and Rhodes' classification of networks and whether different types of networks have more, or less, influence over policy. As such, we first explore critiques of the Marsh and Rhodes classification of types of networks by Jordan et al. (1994) and, earlier, by Read (1992).

Jordan et al. (1994) raised the question of the relationship between the networks involved in policy sectors and related sub-sectors, focusing on UK agricultural policy. They emphasized the increasing fragmentation of the agricultural policy sector, arguing 
that the creation of policy niches, or sub-sectoral policy areas, in which specialized interests predominated, together with the growing role of retail and consumer interests, had undermined the role of the existing policy community dominated by the then Ministry of Agricultural Food and Fisheries (MAFF) and the National Farmers Union (NFU). Cavanagh et al. (1995; for a response, see Jordan and Maloney 1995) responded, acknowledging the growth of sub-sectors and the fact that, to an extent at least, the sectoral community has to accommodate this diversity, but arguing that the operation and influence of the sub-sectoral networks remained significantly constrained by the sectoral policy community.

This debate has not featured heavily in the policy network literature (although see Cavanagh 1998; Greer 2002), but it is an important one, given that the increased complexity of contemporary policy-making inevitably means an increase in the number of policy networks. Perhaps the most interesting recent contribution to this literature is Rayner et al.'s (2001) plea for a much more nuanced understanding of the relationship between sectoral and sub-sectoral networks on the basis of a study of forest policy-making in Canada. More specifically, they make three claims. First, increasingly, policy debates cluster around a few key issues which attract distinct policy sub-sectors with observable policy networks. Second, although sectors may be disaggregated, in many cases there are sectoral networks which affect policy outcomes. Third, they argue:

stability results because of the key structural roles played by specialized, or nodal, critical subsectors which occupy a central location allowing them to constrain policy development in other subsectors and hence constrain the overall direction of sectoral developments.

Read (1992) took issue with Marsh and Rhodes' idea that policy areas were characterized by the existence of either policy communities or issue networks. Instead, he argued that, in smoking policy, there was both an issue network and a policy community. In the issue network, the tobacco industry contested the ethics of smoking and the merits of controls on smoking with anti-smoking groups such as ASH. This 'issue network' was characterized by deep disagreement and little co-operation between the different groups active on this issue. On the other hand, in the policy community, the various tobacco interests negotiated the details of tobacco policy on taxation and other issues with government in an atmosphere of agreement and co-operation and with the anti-smoking lobby excluded.

Overall, these critiques suggest three questions which we shall address in our case study of the CA:

1. Is there sub-sectoral network proliferation?

2. Is there evidence of critical sub-sectors, or a powerful sectoral policy community that constrains outcomes?

3. Can an issue network and a policy community both exist in the same policy area?

\section{The strengths and weaknesses of the two approaches}

Of course, identifying the strengths and weaknesses of the variants of these two approaches is an empirical question, one which will be the main focus of what follows. However, it is important to emphasize that Grant and Marsh and Rhodes had different starting points which, in our view, are reflected in some of the subsequent critiques of their work. So, the focus of Grant's classification is upon individual interest groups and their relations with government. Indeed, some authors who use Grant's distinction as a starting point, 
notably Binderkrantz (2005) and Page (1999), go further and use the groups' own reports of these contacts as their indicator of insider status. This has obvious problems, given that most groups want to project themselves as important, indeed as insiders, and, as we shall see below, these problems are evident in the CA case. However, our main point is that we cannot assess a group's status independently of the role of other groups in the same policy area(s). There is a clear tendency for the insider/outsider literature to do so and this is an omission addressed by the policy network approach. In contrast, because it focuses on particular networks, Marsh and Rhodes' approach tends to pay insufficient attention to the issue of multiple network membership. Here, Grant's approach, to the extent that it maps out all a group's contacts with various government departments, can indicate the variety of that group's contacts and remedy that omission. In our view, therefore, there is a strong prima facie case for combining the strengths of these literatures.

\section{THE COUNTRYSIDE ALLIANCE'S ROLE}

The CA is certainly worthy of study. It is an extremely large interest group, with 105,000 members and 250,000 associate members, membership being predominantly male, older, more educated and with relatively high incomes (Lusoli and Ward 2005). In addition, it has received extensive press coverage, particularly in relation to the issue of foxhunting (see Wallwork and Dixon 2004; Anderson 2006); indeed, as we shall see, many groups with which the CA deals are extremely critical of its pursuit of publicity. Our aim here is to assess the extent to which the two bodies of literature considered earlier help us analyse the role of the CA in contemporary politics and policy-making.

We will also use the case study to reflect back on the conceptual debates. In our view, a single case study can contribute to conceptual and theoretical development (for a broader discussion, see George and Bennett 2005) because conceptual/theory building is an iterative process. Here, we build on a critical review of previous conceptual development, examine the utility of those concepts in relation to the case study, and then reflect back on how the concepts can be developed to be more useful in explaining other cases.

\section{The Countryside Alliance: an insider or an outsider group?}

Here we address three questions on the Countryside Alliance (CA) derived from the literature:

1. Does the CA pursue insider and outsider strategies at the same time?

2. Does the CA pursue an outsider strategy, particularly using the media, because they have no choice, or do they do it to attract members?

3. Does the CA have influence?

The CA was formed in 1997, essentially to campaign on foxhunting. Its forerunner, the British Field Sports Society (BFSS), had been established in 1930 to oppose the first Private Members' Bill, sponsored by the RSPCA, which proposed to ban deer hunting with dogs (BFSS 1931). However, there was a significant increase in anti-hunting pressure in the early 1990s and, in particular, there was a growing concern among the field sports community that the Labour Party would win the next election. In this context, two small organizations, the Countryside Movement and the Countryside Business Group, were formed in mid-1995; these groups merged with the BFSS to form the Countryside Alliance (CA) in 1997 (for further details, see Anderson 2006).

As such, there were two related reasons for the formation of the CA. First, the aim was to provide a more politically acceptable face for the field sports community, to attempt 
to prevent it being seen as a single issue interest group (Anderson 2006). Second, the intention was to mobilize wider rural concerns in support of foxhunting. Nevertheless, as we shall see, the CA's overwhelming concern is with foxhunting.

Of course, foxhunting is a particularly politicized and divisive issue which in the second term of Labour government occupied 700 hours of Parliamentary time. Just to set this in context, according to the Guardian (2005a), this compared to seven hours discussion on the decision to invade Iraq.

If we utilize Grant's classification, the strong public campaigning activity of the Countryside Alliance suggests that it is an 'ideological outsider' group, while, in Binderkrantz's (2005) terms, it mainly utilizes indirect strategies, notably involving marches and demonstrations. Of particular importance here was the Liberty and Livelihood March on 22 September 2002, which the Countryside Alliance claimed attracted over 400,000 people and was 'the largest civil liberties march in modern history' (Countryside Alliance 2009).

In addition, as Binderkrantz might expect, the CA was extremely active in using the media. Indeed, a Lexis-Nexis search for 'foxhunting' articles in the Guardian and the Times for the period Jan 2002-Dec 2005 (see table 1) shows the extent of coverage of the issue in the period up to the passage of the Hunting Act (2004), banning hunting with dogs. The Hunting Bill was given its Third Reading in the House of Commons by a vote of 339 to 155 in September 2004 and became law in February 2005. Most of the news coverage at the time focused fairly heavily on the CA's activities and this was reflected in significant monthly variations (for a more detailed study of newspaper coverage of the Liberty and Livelihood March, including a consideration of the stances individual newspapers took, see Anderson 2006). As Anderson (2006, p. 724) emphasizes, the hunting lobby, with the $\mathrm{CA}$ at the forefront, succeeded in gaining a great deal of coverage of the marches, so the Guardian had 25 articles in September 2002, the vast majority covering the Liberty and Livelihood March, and votes in Parliament, so there was a peak when the Bill was passed in September 2004, with 20 articles in the Guardian and 13 in the Times. It might also be interesting to note here that there was almost double the coverage in the Guardian when compared to the Times: 259 to 131 articles in the whole period.

As Binderkrantz might expect, there is a clear link between coverage of foxhunting and the CA in the media and its recruitment and fundraising. According to the CA's 2005 Annual Report, it spent 56 per cent of its 2004 and 2005 income on campaigning and a further 10 per cent on fundraising, the rest going to finance administration and membership costs (Countryside Alliance 2005). The CA, along with other hunting groups, offers liability insurance as what rational choice analysts would call a 'selective incentive' to join. Its annual income is in the range of $£ 6-8$ million, with just over half of this income coming from donations, partly from regional fundraising efforts and partly from wealthy landowners based around the London area (Barnett and Honigsbaum 1999a). We do not

TABLE 1 Coverage of fox hunting in the Guardian and the Times 2002-2005 (number of articles)

\begin{tabular}{ccc}
\hline Year & Guardian & Times \\
\hline 2002 & 87 & 36 \\
2003 & 71 & 35 \\
2004 & 62 & 44 \\
2005 & 39 & 16 \\
\hline
\end{tabular}


have monthly CA membership figures, but their membership rose between 2002 and 2004 when, as we saw, coverage of their actions against the Bill was greatest.

Of course, the CA is well aware of the link between coverage and income, so it is unsurprising that, in 2006, of the 24 of its staff based at the London HQ, 3 work in the Press Office, two in campaigns and 3 in the political section, while only two are engaged in policy work (personal communication from CA Administrator 22/11/06). None of those employed in the English regions is engaged in policy work; rather, they are largely concerned with recruiting and retaining members (Interview with Claire Rawson, Midlands Regional Director 16/1/07).

In addition, in 2006, the CA employed around 50 staff outside its HQ. These staff members, many of whom were based in an office in Marlborough, were concerned with organizing events, recruitment, fundraising and regional organization activities. In 2002, the CA also employed a further 20 people who were involved in organizing that year's march, but these were laid off soon afterwards. Put simply, the CA spends a majority of its limited resources on media relations and popular mobilizations, rather than research and policy preparation.

To date, it might appear that the CA is simply an 'outsider by necessity' in Grant's (1978) terms and an outsider by ideology in Maloney et al.'s (1994), at least in relation to a Labour government on the hunting issue, but the situation is rather more complex because the CA also pursued an insider strategy and claimed insider status and influence on foxhunting as well as on other issues. The CA talked to government ministers and civil servants about the issue, gave detailed evidence to the Burns Report on hunting and lobbied MPs. In this context, it argues that it was able to use its insider status to prevent the Labour government from backing anti-hunting legislation during its first seven years in office, despite a hostile Labour Parliamentary majority (interview with James Legge, Countryside Alliance Political and Legal Advisor, 06/04/05). This seems, at best, an exaggerated claim and indicates that an interest group's own assessment of its role has to be viewed sceptically. Indeed, our interviews within DEFRA, the Department for Environment, Food and Rural Affairs, would suggest that while the CA may see itself as an insider group on the foxhunting issue, it does not have insider status as far as ministers and civil servants are concerned. In this vein, one DEFRA civil servant argued that the Countryside Alliance, unlike the Country Land and Business Association (CLA; formerly the Country Landowners Association), who also opposed the Hunting Bill, were seen as extreme on this issue and that this affected the quality of the organization's access and reception in Whitehall.

Perhaps more interestingly, the CA had clear links with the Middle-Way Group, a group of MPs and lobbyists who were arguing for a compromise solution involving 'licensed' hunting, and their flirtation with this Group indicates some of the problems which can arise if a group simultaneously pursues insider and outsider strategies on the same issue.

The Middle-Way Group was established in 1998 by Kate Hoey, the Labour MP for Vauxhall, at present the Chairman of the CA, and its first activity involved tabling a series of amendments promoting licensed hunting to the Labour MP for Worcester, Michael Foster's, Private Members Bill to ban hunting in the 1997/8 Session. The Group now has three joint chairs, Baroness Golding (Labour, House of Lords), Peter Luff (Conservative MP for Mid-Worcestershire) and Lembit Opik (Liberal MP for Montgomeryshire). Initially, it was linked to the Wildlife Network, an animal welfare organization and, according to the Observer (Barnett and Honigsbaum 1999b), in 1998 the CA gave $£ 46,500$ towards its administrative and conference costs. In practice both the CA and the Middle-Way Group 
supported a (limited) version of licensed hunting and it is difficult to detect differences in the official positions of the two groups.

Three points seem important here. First, if a group pursues both insider and outsider strategies on the same issue, then these strategies need to be coherently integrated. In this case, the insider strategy was pursued half-heartedly at best, in large part because an insider strategy involves significant policy compromises; compromises which the CA was unwilling, or unable, to make.

Second, the simultaneous pursuit of insider and outsider strategies is likely to confuse, and even alienate, the membership. Most CA members opposed any compromise, so, if the CA had gone further in accepted a more restricted notion of licensed hunting, this would have led to considerable organizational problems. Indeed, the fact that the CA had flirted with the Middle-Way Group alienated some of its more extreme members and may have played a role in the creation in May 2001 of the Real Countryside Alliance (RCA) which not only opposed all compromise, but advocated the use of more militant tactics and was strongly critical of the CA. So, just before the Hunting Bill was passed, RCA activists descended on Westminster, five of them storming into the Commons Chamber itself (Telegraph 2004) and causing chaotic scenes inside and outside Parliament. This was the worst breach of Commons security since the Second World War and, subsequently, for the first time ever, armed police were placed at all entrances to the Chamber. Similarly, in the run-up to the 2005 Elections, threats from the RCA led to ministers being given 24-hour Special Branch protection. It should be added that the Labour government was here following well-established precedent: governments tend to avoid becoming directly involved in issues with clear moral dimensions, most notably abortion, capital punishment and homosexuality, because they see them as no-win issues which may affect their electoral chances (see Marsh and Read 1988). All of this reduced Whitehall's and Westminster's trust in the CA, while, at the same time, making the organization aware that it might be outflanked on the issue if it compromised too much with the government.

Third, an insider strategy, involving some compromise, is much more likely to be successful than an outsider strategy on a very political issue. In this case, a number of senior DEFRA officials we interviewed suggested that, if the CA had played a different hand and accepted government proposals for licensed hunting earlier, then the outcome could have been different, although this view may underestimate the role of Labour Party backbenchers on this issue. In addition, any deal offered to the CA by the government would have probably involved a version of licensed hunting that was too restrictive for the tastes of the CA and which they could not have accepted without alienating the majority of their membership.

Initially, the Middle-Way Group gained a sympathetic hearing from Alun Michael (Labour and Co-operative MP, Cardiff South and Penarth) and other government ministers dealing with the Bill. The newly elected Labour government was reluctant to give active support, and Parliamentary time, to a foxhunting bill (see Guardian 2005c). However, the issue refused to go away and the positions of both sides hardened, in part as a result of the CA's outsider activities, and Labour backbenchers would not accept the Middle-Way Group's 'compromise'. The invasion of Iraq in early 2003 and the subsequent growing hostility towards the government from a large number of Labour backbenchers also significantly changed the government's strategic calculations. In this context, the government was willing to allow Parliamentary time for anti-hunting legislation, even though an outright ban was not its preferred solution; this represented an easy concession to radicals on the backbenches. 
The CA's insider activity on hunting was unsuccessful because it was, at best, halfhearted, while the political environment was conducive to a total ban on hunting. In such a context, the CA had little choice but to continue to use outsider tactics on hunting. By contrast, BASC, which enjoyed much closer insider relations with the government, negotiated an exemption in the Hunting Bill for gamekeepers to confront foxes underground. This arrangement was condemned by pro-foxhunting allies of the Countryside Alliance such as the MP Nicholas Soames (Soames 2003).

While acknowledging its primary interests in countryside sports, the CA also claims that it acts in partnership and cooperation with other countryside groups, such as the NFU and the CLA, on a wide range of other countryside issues, especially food, the environment and housing. Indeed, Anderson (2006, p. 724) argues that this was one of the raison d'êtres of the CA: 'Previous experience had taught the BFSS that public support for its cause could not be generated by the hunting issue alone' (see also Wallwork and Dixon 2004). So, the CA became engaged in other issues to attract and retain support, although in our view this remained very much a secondary concern. In addition, its efforts to attain insider status and affect policy on other issues were limited. As such, the CA plays a very minor role in the rural policy-making processes, even though, given its vocal resistance to banning foxhunting, its public profile is high.

The structure and publications of the CA are revealing here. As we have said, only two of the Countryside Alliance staff work on policy. In comparison, the British Association for Shooting and Conservation (BASC) has more than 100 staff in total, with 80 working on 'operational issues', covering research, policy and, especially, land management issues. Obviously, this comparison reflects the CA's priority which is hunting and the dominant outsider strategy it utilizes. The BASC's relationship with government is diverse and illustrates the complex nature of interest group relationships existing inside and outside government. As a senior shooting spokesperson put it: 'To the DCMS, we're people who win medals at international championships. To DEFRA, we are an essential conservation group. To the Home Office, we're just people with guns' (unattributable interview with senior shooting organization official 6/12/06).

Table 2 presents a content analysis of the issues covered in the monthly 'Updates' the CA sends to members. Most of the coverage is concerned with either hunting issues or internal organizational/fundraising issues and events. There is little in the way of detailed policy coverage of other rural issues and certainly nothing that suggests that it is involved in detailed policy-making on a range of rural policy issues, for example, the disbursement of agricultural subsidies.

The CA's relative lack of resources and its focus on foxhunting and publicity makes it difficult for it to do detailed policy work and pursue insider activity on general rural

TABLE 2 Content analysis of the Countryside Alliance 'updates', 2005-2006

\begin{tabular}{lc}
\hline Topic & Percentage of coverage \\
\hline Fox hunting & 27 \\
Shooting & 33 \\
Angling & 11 \\
Internal CA & 19 \\
General rural & 10 \\
Total & 100 \\
\hline
\end{tabular}


issues. On the other hand, it does have great skill in communications, campaigns and in assuring the rapid issue of press releases in response to announcements from government. This has resonance with Binderkrantz's arguments, but it doesn't make it popular with others in the rural lobby.

Perhaps the key problem for the CA is that the different strategies that it pursues are contradictory. This is a simple, but very important, point. The Labour Party is in government, but given the party-divide on foxhunting, much of the CA's activity is directed against Labour MPs. This was most evident when an organization, strongly supported by the CA, called Vote-OK was launched as 'the electoral wing of the hunt lobby' six weeks before the 2005 Election. Vote-OK claimed to have committed 170,000 'campaigning man hours', delivered 3.4 million leaflets, hand-addressed 2.1 million envelopes and put up 55,000 posters. It targeted 139 marginal constituencies in which sitting MPs had supported the Hunting Bill and where the second placed candidate opposed a ban.

After the election, Vote-OK claimed partial responsibility for defeating 29 anti-hunting MPs, reducing the majorities of 21 other anti-hunting MPs to less than 3 per cent and boosting the majority of 9 pro-hunting MPs. While it is difficult to access such claims, if we take the 5 defeated MPs specifically named by the Countryside Alliance and/or the Guardian (Guardian 2005b), Peter Bradley, Labour MP for the Wrekin, Helen Clark, Labour MP for Peterborough, David Rendell, Liberal Democratic MP for Newbury, Steven Twigg, Labour MP for Enfield Southgate, and Candy Atherton, Labour MP for Falmouth and Camborne, then there is evidence that they may have had some influence (table 3). In each case, the swing against the sitting MP was greater than the average swing in the region of which the constituency was a part.

Of course, this strategy is hardly likely to endear it to Labour MPs or the Labour government. As we saw, the CA are clearly outsiders on the foxhunting issue and this crucially affects their access and influence on other issues. For example, while shooting and fishing interest groups try, in general, to keep good relations with Labour MPs, many of those MPs are diametrically opposed to the CA on hunting. In this vein, Martin Salter, Labour's Parliamentary Spokesperson on Fishing and Shooting, has supported many of the demands made by shooting and fishing groups, but he has been conspicuously at odds with the Countryside Alliance (Press Release by Martin Salter MP 2005), which is hardly surprising, given, through Vote-OK, they were openly campaigning for his Conservative opponent at the 2005 election.

The inevitably anti-Labour tenor of its campaign on foxhunting inevitably militates against the CA acting as an insider group on hunting and fishing issues under a Labour

TABLE 3 The hunting issue, Vote-OK and the 2005 General Election

\begin{tabular}{lccc}
\hline MP and constituency & $\begin{array}{c}\text { Fall in \% of } \\
\text { vote 01/05 } \\
\text { elections }\end{array}$ & $\begin{array}{c}\text { Average change } \\
\text { in party vote in } \\
\text { region }\end{array}$ & $\begin{array}{c}\text { Target seat number } \\
\text { for successful party } \\
\text { (in brackets) }\end{array}$ \\
\hline Peter Bradley, Lab, The Wrekin & 7.2 & -6.1 & 58 (Con) \\
Candy Atherton, Lab, Falmouth and Camborne & 8.6 & -3.5 & 41 (Lib Dem) \\
David Rendell, Lib Dem, Newbury & 5.6 & +1.7 & 30 (Con) \\
Stephen Twigg, Lab, Enfield-Southgate & 11.3 & -8.4 & 114 (Con) \\
Helen Clark, Lab, Peterborough & 9.6 & -7.0 & 43 (Con) \\
\hline
\end{tabular}

Source: Constructed from information on the BBC Election 2005 web site (http://news.bbc.co.uk/1/ hi/uk_politics/vote_2005/default.stm). 
government and also undermines any influence it might have with the Labour Party on wider rural concerns. It may be consulted by DEFRA because it has some expertise, but, as a senior DEFRA official emphasized: 'Invariably, if there's a rural issue, then the CLA, not the CA, is going to be there' (Interview 6/12/05). The CA is less involved for two main reasons. First, it is a recently formed organization, while the CLA was formed in 1907 and, as such, has a long history of contact with DEFRA and its forerunners, especially the Ministry of Agriculture, Food and Fisheries. Second, and crucially, DEFRA is wary of the CA because of their stance on foxhunting.

Unsurprisingly, the CA contends that it has insider status which gains it influence. Indeed, in this vein, senior Countryside Alliance officials claimed 'insider' discussions had achieved a number of detailed, but significant, changes in 'field sport' policy, for example, limiting restrictions on firearms and strengthening proposals to protect animal welfare (interviews John Gardner 06/04/05 and James Legge 26/09/06).

In contrast, representatives of shooting and fishing organizations decry the notion that the CA makes significant contributions to policy formation or the achievement of policy objectives. Indeed, there are complaints from officials of shooting and fishing organizations that the CA tries to claim credit in the media for other's successes (unattributable interview with senior shooting official 06/12/06; interview with Paul Knight, Salmon and Trout Association (STA) 08/01/07

Thus, Paul Knight from the STA claimed:

We liaised with Fisheries Minister Ben Bradshaw to negotiate what we thought was a good agreement on control of cormorants. Immediately afterwards comes a press release from the Countryside Alliance claiming victory. We got our press release out two days later. People assumed reading the press that the CA had been a central mover on this, but they played almost no part, apart from sending a letter to the Minister.

Overall, then, the CA pursues both insider and outsider strategies, but contrary to May and Nugent, it has used both strategies at once. As Page might expect, they use different strategies on different issues; outsider action was used in relation to the foxhunting issue, while insider activity was simultaneously undertaken on broader rural issues. In addition, however, they used both insider and outsider activity on the foxhunting issue; although the outsider activity was more obvious, while the insider activity was limited and half-hearted. On foxhunting, the CA has little choice but to rely mainly on an outsider activity because they do not have insider status on this issue with a Labour government.

One of Grant's original contentions was that groups who pursue outsider strategies have no, or at best very limited, direct contacts with government, because, to a large extent, insider status is based upon trust. This is clearly the case with the CA, which, unsurprisingly, is not trusted by the Labour government, given that it tried to unseat Labour MPs at the 2005 election and has subsequently taken the government to court on two occasions over the hunting ban. At the same time, as Grant emphasized, insider relationships are exchange relationships. On hunting, the CA has little to offer government, unless it is willing to compromise. As we saw, it did partially fund the Middle-Way Group, but this was a limited and inevitably unsuccessful strategy. In addition, once the legislation was passed, the CA's actions in the courts and on the campaign trail were hardly designed to encourage dialogue.

Elsewhere, on broader rural policy, the CA has something to offer government in terms of expertise in these areas and the legitimacy it derives from a large, mainly rural, membership. However, it seems clear that other groups have more involvement than 
the CA. At the general level of agricultural policy, the NFU is still, overwhelmingly, the dominant actor. As regards rural policy, the CLA occupies a central position. Elsewhere, 'niche' groups have an important role. BASC, for instance, is central in the area of shooting, although it is involved in contestation with animal welfare organizations, while groups such as the STA are consulted on the narrower area with which they are concerned. In contrast, the CA seems to us to have a more peripheral role on rural policy issues, which reflects both its limited policy concerns and the lack of trust the government has in it. The problem is that there is a key tension between the CA's two aims and the strategies associated with attaining them. To the extent that it uses outsider tactics on foxhunting, resorting to legal challenges, electoral action (which largely means attempts to unseat Labour MPs), and media attacks, then it is unlikely to achieve insider status on other issues. This was certainly clear from our interviews with DEFRA.

Binderkrantz's (2005) typology of interest groups appears useful here since it contrasts groups who focus mainly on 'direct' strategies with those who use 'indirect' strategies. Given its avowed, and to other groups irritating, prowess in obtaining publicity, and its evident success in mounting demonstrations, the CA is very strong on 'indirect strategies'. However, the earlier discussion indicates that its use of 'direct strategies' is less successful. It also suggests that, while the CA's use of the media may attract, and to an extent placate, members, it alienates both the government and the other groups with whom it needs to develop common cause. Almost all the representatives of 'rural' groups we talked to were critical of the CA's use of the media and particularly of their tendency to claim credit for others' efforts.

A key problem with Binderkrantz's survey methodology is that she asked interest groups about the contacts they had with government. As we emphasized, when we asked the CA about their 'insider' contacts, they reported a large number of productive contacts. However, civil servants in DEFRA reported a different pattern, suggesting the CA's contacts were limited, if not non-existent; in Maloney et al.'s terms they do not have insider status, even when they use insider strategies. To put it another way, they are on the consultation lists, but other groups, both groups with broader interests and 'niche' groups, have better insider contacts. Most pertinently in relation to Binderkrantz's conclusions, their use of outsider strategies on foxhunting reduces their insider status, and their influence, in other policy areas.

Overall, while the distinctions discussed here have some resonance, it seems to us that they focus too heavily upon the bilateral relations between interest groups and government. However, such relationships, to the extent that they exist, occur within a broader context and set of relationships, that is within a policy arena structured by the existence of a series of policy networks. It is thus difficult to appreciate the role and influence of the CA without understanding how it relates to other groups: that is, what role it plays in the policy networks in the policy areas with which it is concerned.

\section{The Countryside Alliance and policy networks}

Here we address three questions:

1. Is there sub-sectoral proliferation?

2. Is there evidence of critical sub-sectors, or a powerful sectoral policy community that constrains outcomes?

3. Can an issue network and a policy community both exist in the same policy area and of which is the CA part? 
However, these three questions pre-suppose a prior one: what types of networks are the CA involved in?

As policy-making has become more complex, there is clearly greater sub-sectoral proliferation, as is evident from the discussion to date, although, of course, it is not always, perhaps not even usually, easy to specify the boundaries of particular networks. It is easier to do this if networks are tight, and particularly if they have an institutional manifestation, as was the case with the archetypal policy community in agriculture (see also Smith 1990, as discussed above). Here, we rely on our interviews with groups and civil servants for evidence of the presence and shape of policy networks, but recognize that groups, like the CA as we saw earlier, are highly likely to claim better contacts, and greater insider status, than they actually enjoy.

With the unsurprising exception of our interviews with the CA itself, all our respondents indicated that the CA is a peripheral group in all the policy networks with which it is involved, with the exception of the hunting issue. Here, the CA is perhaps the most visible and active anti-hunting group, but other groups were broadly on its side, although some with important reservations. The CLA opposed a ban, arguing that landowners should have the right to decide how foxes on their land were controlled (CLA Press Release 9/9/04). In contrast, while the NFU was broadly opposed to a ban, it was prepared to accept the Middle-Way Group's compromise which would have allowed licensed hunting (NFU Press Release 9/9/04). On the other side were ranged a series of anti-hunting, animal welfare, and animal rights groups, the most important of which was Campaigning to Protect Hunted Animals (CPHA), a joint initiative established in 1996 by the International Fund For Animal Welfare, the Royal Society for the Protection of Animals and the League against Cruel Sports to push for a complete ban on hunting.

Of course, governments prefer to avoid emotive issues such as hunting, where they see only a political downside, so they will talk to interested groups in the hope of some compromise. However, in this case there was not enough common ground. The government, the Middle-Way Group and even the NFU could have compromised on a licensing system, but that was not acceptable to the CA, CPHA or most Labour backbenchers. In fact, hunting is a classic issue network. There are no private interactions between the groups, although there is a great deal of public posturing towards one another; the two 'sides' have almost totally divergent policy preferences, with little, or no, room for any compromise; if leaders attempted compromise, they would place themselves in a very vulnerable position; so, outcomes inevitably involve a zero-sum game.

If we move to the broader issue of shooting, the BASC claims to represent the bulk of wildfowlers (unattributable interview with senior official of shooting organization $6 / 12 / 06$ ) and it certainly has more staff and a much broader credibility in this area than the CA. Here, there is a network which includes the BASC and the RSPCA, as well as more radical groups such as the League Against Cruel Sports. As part of this network, the BASC does attempt to work with both government and animal welfare groups, because it both wants to influence policy outcomes and separate the animal welfare from the animal rights lobbies. The CA is involved in this network, but is more marginalized, not only because of its belligerence on hunting and lack of detailed policy expertise, issues raised earlier, but also because of its less liberal position on certain animal welfare issues. As an example, while both BASC and CA lobbied MPs and government to stop tail docking of gun dogs being banned in the 2006 Animal Welfare Act, the BASC accepted that tail docking for 'cosmetic' purposes should be banned, while the CA was neutral on this issue (interview with John Gardner 13/12/06). Similarly, BASC has called for the banning of 
'battery farming' (called 'raised laying units' by the CA) of pheasants and partridges, while the CA instead supports a 'code of practice' produced by the Game Farmers' Association which would continue to allow the practice (Game Farmers Association 2005; Countryside Alliance 2006). Here, it appears that the CA are more supportive than BASC of the landowners who run commercial shoots and are most interested in reducing the costs of game bird production: a position which puts them clearly at odds with the animal welfare lobby.

The CA is also marginalized in what we might call a 'water-based conservation policy network' which involves a range of environmental, governmental and fishing actors. This network is concerned with issues of conservation, land and water management, including, for example, the delivery of water legislation, sewage disposal policy, sheep dips and conservation of fish and animal species in general. Groups such as the RSPB (Royal Society for the Protection of Birds), the wildlife trusts, the National Trust and the WWF (World Wildlife Fund) are active in water conservation issues because of their interest in wildlife conservation, while the interested governmental actors are Natural England, the Environment Agency and, of course, DEFRA. The CA is rarely involved on such issues. So, for example, it is not a member of the Fishing and Conservation Trust (FACT), which brings together the Angling Trade Association, coarse fishing associations, sea angling associations and the salmon and trout associations to discuss issues about fish stocks and so on. Similarly, it is not involved in the 'Blueprint for Water' initiative organized by fishing and conservation groups (Blueprint for Water 2006).

The water-based conservation policy network is very different from the hunting issue network. There is negotiation, discussion and compromise; so, for example, the RSPB does not campaign against shooting or fishing. At the same time, there are significant disagreements which reflect the different interests of network participants and this was reflected, for instance, in the arguments between the RSPB, on the one hand, and shooting and fishing interests on the other hand, over the issue of the control of cormorants.

This water-based conservation network overlaps with what could be called a land conservation network which includes the conservation NGOs mentioned above as well as DEFRA and Natural England. However, the BASC is also active in this network, because its shooting membership manages a large proportion of land and over 700,000 acres of land designated as SSSIs (sites of special scientific interest). Indeed, it has been accorded special status with DEFRA in management of SSSIs (unattributed article Shooting Times 1998). DEFRA was created in 2001 when the Ministry of Agriculture, Fisheries and Food (MAFF) was merged with the Department of the Environment, Transport and the Regions. Again, the CA is, at best, marginal to this network.

Overall, then, the CA is crucial in only one network and it is a classic issue network, marked by confrontation and an absence of consensus or compromise. It is also worth emphasizing again here that its presence and action in that issue network compromises its involvement and influence in other networks. Here, the general point is simple. We need to examine multiple and overlapping memberships and recognize that action in one network may affect a group's role in other networks.

We also need to recognize, indeed emphasize, that some groups are much more integrated into the policy networks linked to DEFRA than others. DEFRA is divided into seven Directorates (DGs), of which four deal with policy: Sustainable Farming and Food; Environment; Animal Health and Welfare; and Living, Land and Sea. The other three Directorates are Law and Regulation; Operations; and Science, Economics and Statistics. In common with other Departments of State there is also a strategy unit. There are a 
number of 'teams' in each DEFRA Directorate which have close contacts with interest groups in a series of policy networks. As such, Jordan et al. (1994) are clearly right in stating that there is a proliferation of policy networks in the areas with which DEFRA is concerned. An example of a network taken from our own interviews, the network linked to the Common Agricultural Policy Unit in the Sustainable Farming and Food Directorate, illustrates some of the processes involved.

In this network, the NFU remains the single most important actor, other than the department itself, although four other groups, the CLA, the Tenant Farmers Association (TFA), the Central Association of Agricultural Valuers (CAAV) and the British Institute of Agricultural Consultants (BIAC) are also members of what a member of the DEFRA unit called the 'implementation group', and we would term a fairly tight policy network. These groups are in the policy network because they have policy expertise that the department wants and, in the case of the NFU and, to a lesser extent, the CLA and the TFA, are crucial groups if policy is to be effectively implemented. However, when policy reviews are being undertaken or policy changes being considered, these groups will be joined by English Nature (now Natural England), the Environment Agency, the Countryside Agency, the RSPB, Sustain (an alliance of environmental and consumer groups), the Consumers Association, the Food and Drink Association and the British Retail Consortium. Unsurprisingly, the CA plays no role (interview with senior DEFRA official 16/02/07). In effect, and as Read might expect, there is an inner, fairly tight, policy network and an outer issue network, which is consulted, but appears less influential. In the inner network, the NFU may be particularly important, but tension is reduced, according to a DEFRA insider, because there is a broad policy consensus.

We do not have the data to assert that there is a critical sub-sector, but it is clear from our interviews, and we don't find this surprising, that some groups, notably the NFU, but also to an extent the CLA, do occupy critical positions across a broad policy arena as members of a series of fairly tight policy networks. As such, it may be better, at least in this case, to talk of critical groups, which are present and influential across a broad area of policy-making. So, while, as Maloney et al. (1994) emphasized, we need to recognize proliferation, we also need to acknowledge network overlap, multiple network membership and the presence of particularly powerful, critical, groups across a broad span of policy areas.

Finally, in our view, this discussion of the policy networks in which the CA is involved seems to confirm the utility of Read's (1992) argument. The CA is consulted on a variety of issues about rural policy to the extent that it is on departmental, especially DEFRA, consultation lists. As such, it is part of a series of issue networks. However, the CA does not appear to be part of any of the policy networks in which negotiation over policy occurs. It is on the periphery, not at the core, of the networks. As such, it seems important to us to recognize that broader issue networks, which include a larger number of groups or interest, provide part of the context within which policy networks/communities operate.

\section{CONCLUSION}

In our view, this case study of the CA suggests a number of ways forward for the conceptual literature on interest groups. In particular, we would suggest that we can combine insights from both the insider/outsider literature and the policy networks 
literature to develop a better characterization of types of interest groups and policy networks. More specifically, we would make 5 claims:

1. While Grant is right that different groups pursue different strategies in their dealings with government, his distinction between insider and outsider groups, even in its later version, is of limited utility. So, the CA has used both strategies. In effect, in Maloney et al.'s terms, they have outsider status, even when they adopt an insider strategy. In large part, this results from their use of an outsider strategy on foxhunting, which means that there is little trust between the CA and civil servants and ministers. As such, we would agree with Maloney et al. that it is the status that groups have with government, rather than the strategies that they adopt, which is the crucial factor.

2. While Binderkrantz is right to claim that groups may use outsider, or indirect, tactics, particularly involving the media, to attract membership and increase income, in the CA's case at least, the use of such tactics does affect the group's status with, access to, and thus putative influence over, government. Indeed, we suspect that Binderkrantz's conclusion that the use of outsider strategy does not reduce access and influence may result from her use of group's reports of their contacts and influence. As we saw, the CA clearly, and unsurprisingly, over-reports its access and influence.

3. Maloney et al. are right to emphasize the proliferation of policy sectors and thus of policy networks. However, we also need to acknowledge the overlaps between networks and the presence of some groups, we might call them critical groups, in a broad raft of different, but connected, networks.

4. The literature needs to reconsider Read's (1992) argument about the coexistence of issue networks and tighter policy networks in the same policy area. In most of the areas in which the CA is involved it is on the periphery: creating noise, but having little effect in the policy network and on policy outcomes.

5. The insider/outsider literature focuses much too heavily on bi-partite relations between a group and government. This can reveal a lot, particularly if we recognize that groups use different strategies in different policy areas. As such, it is good for examining the number and scope of, and perhaps contradictions between, the links between a group and government. So, for example, it would inevitably highlight whether the contact a group has with government on one issue affects their contacts on other issues, as was clearly the case with the CA. However, there are problems with this focus on bi-partite contacts. First, there is almost inevitably a methodological problem. If we focus on one group, we are likely to overestimate their access and influence, because, like the CA in this case study, they overestimate their insider status. A focus on networks gives us triangulated data and, consequently, we have a broader picture of the contacts a particular group enjoys, so, as we saw in this case study, other groups have different attitudes about the status and influence of the CA. However, the big weakness of a focus on bi-partite contacts is that it fails to appreciate the variety of interactions that a group has with other groups within various networks and the way that the interaction between groups in networks affects policy outcomes.

In our view, then, we need to recognize the existence and role of policy networks, but also acknowledge that different groups in a network use different strategies, depending, to a large extent, on the type of network (outsider tactics are most likely in issue networks and 
least likely in policy communities) and on the group's position and status within a given network (marginal groups are more likely to use outsider strategies). As we emphasized at the outset, the two sets of literatures examined here are clearly related and compatible. As such, utilizing the insights provided by a critical examination of both literatures will deepen the analysis of the role of interest groups in contemporary politics.

\section{ACKNOWLEDGEMENT}

Research for this paper was funded by the UK ERSC under the project: 'The Countryside Alliance: from direct action to insider status' (RES-000-22-1021).

\section{REFERENCES}

Anderson, A. 2006. 'Spinning the Rural Agenda: The Countryside Alliance, Fox Hunting and Social Policy', Social Policy and Administration, 40, 6, 722-38.

Barnett, A. and M. Honigsbaum. 1999a. 'Middle way' group is front for hunt', Observer, 15/8/1999.

Barnett, A. and M. Honigsbaum. 1999b. 'Prince gave hunt lobby secret aid', Observer, 26/12/1999.

BASC. 2005. 'BASC calls for ban on battery cages in game rearing', Press Release issued 22 November 2005 (http://www.basc.org.uk/content/basc_calls_for_ban_on_bat), accessed January 2007.

Binderkrantz, A. 2005. 'Interest Group Strategies: Navigating Between Privileged Access and Strategies of Pressure', Political Studies, 53, 4, 694-715.

Blueprint for Water. 2006. '10 steps for sustainable water by 2015'. London: WWF.

BFSS. 1978. British Field Sports Society, 'BFSS News Bulletin', February 1978. London: British Field Sports Society, accessed in British Library holdings.

British Field Sports Society. 1930. 'Report of a Meeting on 4 December 1930. London: British Field Sports Society, accessed in British Library holdings.

Burge, R. 1999. 'A Forgotten People', Country Sports, Summer, 14-15.

BBC News. 1999. ‘UK Politics Government accused of hunt hypocrisy’ (http://news.bbc.co.uk/1/hi/uk_politics/404853.stm), accessed 17/02/06

BBC News. 2002. 'Huge turnout for Countryside Marches', 22 September 2002, accessed 10/02/06.

Cavanagh, M., D. Marsh and M. Smith. 1995. 'The Relationship Between Policy Networks at the Sectoral and Sub-sectoral Levels: A Response to Jordan, Maloney and McLaughlin, Public Administration, 73, 4, 630-4.

Cavanagh, M. 1998. ‘Offshore Health and Safety Policy in the North Sea: Policy Networks and Policy Outcomes in Britain and Norway', in D. Marsh (ed.), Comparing Policy Networks. Buckingham: Open University Press, pp. 90-109.

Clegg, P. 2002. 'From Insiders to Outsiders: Caribbean Banana Interest in the New International Trading Framework', Revista Europea de Estudios Latinanericanos del Caribe, 73, 1, 65-81.

Countryside Alliance. 2005. 'Annual Report \& Summary Financial Statements'. London: Countryside Alliance.

Countryside Alliance. 2009. 'Campaigning Landmarks'. London: Countryside Alliance, p. 4 (http://www.countrysidealliance.org.uk/images/stories/pdf/2009_landmarks_jan.pdf), accessed March 2009.

Countryside Alliance. 2006. 'Animal Welfare Bill - DEFRA's Response' (http://www.countrysidealliance.org.uk/newsletters_ and_weekly_publications/Last_Week_in_Westminster/Week_to_Friday_11_March/), accessed January 2007.

Doherty, B., M. Paterson and B. Seel. 2000. 'Direct Action in British Environmentalism', in B. Seel, M. Paterson and B. Doherty (eds), Direct Action in British Environmentalism. London: Routledge, pp. 1-24.

Downing, G. 1998. 'Parting Shot', Shooting Times and Country Magazine, 30/04/1998.

Dudley, G. and J. Richardson. 1998. 'Arenas without Rules and the Policy Change Process: Outsider Groups and British Roads Policy', Political Studies, XLVI, 727-47.

Game Farmers Association. 2005. 'GFA Standards' (http://www.gfa.org.uk/page5.html), accessed December 2006.

Guardian, The. 2005a. Stephen Moss, 'A way of ordering the world: foxhunting has been banned, but Stephen Moss enjoys two spirited résumés of its appeal', 19 February.

Guardian, The. 2005b. Duncan Campbell, 'Hunt backers claim scalps of 29 MPs'. 9/7/2005.

Guardian, The. 2005c. 'Government warns hunts over use of prey fo flout ban', 8/10/05.

George, A. and A. Bennett. 2005. Case Studies and Theory Development in the Social Sciences. Cambridge, MA: MIT Press.

Grant, W. 1978. 'Insider Groups, Outsider Groups and Interest Group Strategies in Britain', University of Warwick Department of Politics Working Party no. 19.

Grant, W. 2000. Pressure Groups and British Politics. Basingstoke: Macmillan.

Grant, W. 2004. 'Pressure Politics: The Changing World of Pressure Groups', Parliamentary Affairs, 57, 1, 2. 
Greer, A. 2002. 'Policy Networks and Policy Change in Organic Agriculture: A Comparative Analysis of the UK and Ireland', Public Administration, 80, 3, 452-73.

Jordan, G. and W. Maloney. 1997. The Protest Business. Manchester: Manchester University Press.

Jordan, G., W. Maloney and A. McLaughlin. 1994. 'Characterising Agricultural Policy Networks', Public Administration, 72, 4, 505-26.

Jordan, G. and W. Maloney. 1995. 'Policy Networks Expanded: A Reply to Cavanagh, Marsh and Smith', Public Administration, $73,4,630-4$.

Lo, C. 1982. 'Countermovements And Conservative Movements In The Contemporary US', Annual Review of Sociology, 8, 107-34. Lusoli, W. and S. Ward. 2005. 'Hunting Protestors: Mobilisation, Participation and Protest Online in the Countryside Alliance', in S. Oates, D. Owen and R. Gibson (eds), Civil Society, Democracy and the Internet: A Comparative Perspective. London: Routledge, pp. 59-79.

Maloney, W., G. Jordan and A. McLaughlin. 1994. 'Interest Groups and Public Policy: The Insider/Outsider Model Revisited', Journal of Public Policy, 14, 1, 17-38.

Marsh, D. and R.A.W. Rhodes (eds). 1992. Policy Networks in British Government. Oxford: Oxford University Press.

May, T. and T. Nugent. 1982. 'Insiders, Outsiders and Thresholders: Corporatism and Pressure Group Strategies in Britain', Political Studies Association Conference, University of Kent, April.

McLaughlin, A.M. and W.A. Maloney. 1996. 'Privatization as Industrial Policy: State Withdrawal from the British Motor Industry', Public Administration, 74, 3, 435-52.

Milbourne, P. 2003. 'Hunting Ruralities: Nature, Society and Culture in 'Hunt Counties' of England and Wales', Journal of Rural Studies, 19, 157-71.

Middle-Way Group. (http://www.nwlacs.co.uk/archive/ca_middle_way_group.htm), accessed February 2006.

Page, E.C. 1999. 'The Insider/Outsider Distinction: An Empirical Investigation', British Journal of Politics and International Relations, 1, 2, 205-14.

Peterson, J. 2003. 'Policy Networks', Political Science Series, Institute for Advanced Studies, Vienna.

Plumb, A., D. Marsh, M. Read and D. Toke. 2007. 'Tally-Ho: Parliamentary Voting on Fox Hunting', unpublished mimeograph paper (copy available from david.marsh@anu.edu.au).

Potter, B. 2002. 'Predatory Politics: Group Interests and Management of the Commons', Environmental Politics, 11, 2, 73-94.

Press Release by Martin Salter, MP. 2005. ‘Campaign Against Martin Salter MP?, 15/03/05 (http://www. fishingmagic.com/news/article/mps/UAN/3446/v/1/sp/), accessed January 2007.

Rayner, J., M. Howlett, J. Wilson, et al. 2001. 'Privileging the Sub-sector - Critical Sub-sectors and Sectoral Relationships in Forest Policy-making', Forest Policy and Economics, 2, 3-4, 319-32.

Read, M. 1992. 'Policy Networks and Issue Networks - The Politics of Smoking', in D. Marsh and R.A.W. Rhodes (eds), Policy Networks in British Government. Oxford: Oxford University Press, pp. 124-48.

Richardson, J. and G. Jordan. 1987. Government and Pressure Groups in Britain. Oxford: The Clarendon Press.

SACN (unattributed). 2006. 'New Bass MLS of $40 \mathrm{~cm}$ Announced', Sea Anglers Conservation Network (SACN) (http://www.sacn.org.uk/Conservation-and-Political-News/New_Bass_MLS_Announced.html), 9/08/06, accessed January 2007.

Smith, M. 1990. The Politics of Agricultural Support in Britain. Aldershot: Dartmouth.

Smith, M. 1993. Pressure, Power and Policy: State Autonomy and Policy Networks in Britain and the United States. Hemel Hempstead: Harvester Wheatsheaf.

Soames, N. 2003. 'Government sets trap for gamekeepers', DailyTelegraph, 16 June, page 31.

Telegraph, The. 2004. George Jones, 'Hunt brawl in Commons', 16/09/2004.

Unattributed article. 1998. 'Triumph and disquiet at CA AGM', Shooting Times \& Country Magazine, 11/06/1998.

Wallwork, J. and J. Dixon. 2004. 'Foxes, Green Fields and Britishness: On the Rhetorical Construction of Place and National Identity', British Journal of Social Psychology, 43, 1, 21-39.

\section{Date received 21 February 2007. Date accepted 14 May 2007.}

